\title{
Iatrogenic hypothyroidism and acute psychosis
}

\author{
Lucrezia Islam $^{1 *}$, Anna Maria Masu ${ }^{2}$, Silvio Scarone ${ }^{1}$, Orsola Gambini ${ }^{1}$ \\ ${ }^{1}$ Psychiatric Branch, Department of Medicine, Surgery and Dentistry, University of Milan Medical School and San Paolo Hospital, \\ Milan, Italy \\ ${ }^{2}$ Internal Medicine Branch, Department of Medicine, Surgery and Dentistry, University of Milan Medical School and San Paolo \\ Hospital, Milan, Italy

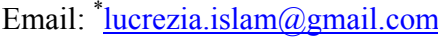

Received 12 May 2013; revised 10 June 2013; accepted 18 June 2013

Copyright (C) 2013 Lucrezia Islam et al. This is an open access article distributed under the Creative Commons Attribution License, which permits unrestricted use, distribution, and reproduction in any medium, provided the original work is properly cited.

\begin{abstract}
We present the case of a 39 years old woman who was referred to our day hospital unit because of anxiety. The patient didn't endorse any past psychiatric symptoms except for an acute psychotic episode in August 2010. In June 2010 she was diagnosed with hypothyroidism (likely due to Hashimoto's thyroiditis) and was started on Methilmazole $30 \mathrm{mg}$. Shortly after that she reported persecutory ideation and hallucinations which quickly progressed, until she was hospitalized in a psychiatric facility. Upon admittance her lab work revealed severe hypothyroidism. Methilmazole was suspended, she was started on Haloperidol, and the symptoms went into remission after four days. Despite the fact that she self discontinued Haloperidol shortly after discharge, she showed no sign of psychotic symptoms. While it is widely accepted that hypothyroidism can cause depressive symptoms, to the best of our knowledge very few cases of psychotic symptoms associated with this condition have been described. Based on the patient's clinical history, on the rapid onset and remission of symptoms, on the lab values and on the doses of medication that were prescribed, we hypothesize that our patient's psychotic episode was caused by iatrogenic hypothyroidism.
\end{abstract}

Keywords: Psychosis; Hypothyroidism

\section{BACKGROUND}

The association between thyroid deficiency and psychiatric presentation is not infrequent $[1,2]$, but is commonly overlooked as an etiology for behavioral, affective, and cognitive changes [3]. Traditionally, lethargy and lassitude were thought to be the typical psychiatric

"Corresponding author. manifestations of hypothyroidism. Studies have shown, however, that $5 \%$ to $15 \%$ of myxedematous patients have some form of psychosis [4].

\section{CASE REPORT}

We present a case of a 39 years old woman complaining of anxiety, who was referred to our Psychiatry Day Hospital unit in September 2010. She said her anxiety had begun about a month earlier, denied substance abuse and any history of psychiatric disorders except for an acute psychotic episode in august 2010.

General medical history was unremarkable except for hyperthyroidism (TSH $0.001 \mu \mathrm{U} / \mathrm{mL}$; fT3 $14.6 \mathrm{pg} / \mathrm{mL}$; fT4 $37 \mathrm{pg} / \mathrm{mL}$ ) which first presented in June 2010, 10 months after the birth of her first child. Anti thyroglobulin and anti thyroperoxidase antibodies at the time were $133 \mathrm{UI} / \mathrm{mL}$ and $146 \mathrm{UI} / \mathrm{mL}$. The subject was started on Methilmazole $30 \mathrm{mg}$ on July 10th 2010 and, two weeks later, she developed auditory and visual hallucinations and persecutory delusions, which worsened until, on July 31 st, she was hospitalized in a psychiatric ward.

Upon admittance she was alert and oriented, and passively cooperant. General examination was normal except for bilateral swelling in the lower lymbs (which had begun 10 days earlier). She was euthymic but anxious because of visual and auditory hallucination (large faces with wigs laughing at her) and persecutory delusions. Lab work indicated severe hypothyroidism (TSH 87.8 $\mu \mathrm{U} / \mathrm{mL}$, fT3 $1.23 \mathrm{pg} / \mathrm{mL}$ and fT4 $1.75 \mathrm{pg} / \mathrm{mL}$ ). Methilmazole was suspended and the patient was started on Haloperidol $10 \mathrm{mg}$.

Four days later her symptoms remitted (at the time of discharge on August 4th she had no hallucinations nor delusions). She self discontinued Haloperidol one week later with no change in her mental status, and no recurrence of psychotic symptoms. At the end of August she started having tremors, anxiety, mood swings and in- 
somnia. Lab work indicated mild hyperthyroidism (TSH $0.15 \mu \mathrm{U} / \mathrm{mL}$, fT3 $4.1 \mathrm{pg} / \mathrm{mL}$, fT4 $12 \mathrm{pg} / \mathrm{mL}$ ).

In mid September 2010 she was evaluated by means of the Hamilton Anxiety Rating Scale (HAM-A), Hamilton Depression Rating Scale (HAM-D), Brief Psychiatric Rating Scale (BPRS) and Scale for the Assessment of Positive Symptoms (SAPS). Her HAM-A score was 22, her HAM-D was 13, her BPRS score was 30 and her SAPS score was 2. Thyroid function was: TSH 0.02 $\mu \mathrm{U} / \mathrm{mL}$, fT3 $4.5 \mathrm{pg} / \mathrm{mL}$, fT4 $1.6 \mathrm{pg} / \mathrm{mL}$; anti thyroglobulin and anti thyroperoxidase antibodies were $60 \mathrm{UI} / \mathrm{mL}$ and $86 \mathrm{UI} / \mathrm{mL}$, respectively. Following an endocrinological consult the patient was diagnosed with Hashimoto's thyroiditis and was started on Methilmazole 10 $\mathrm{mg}$ and Delorazepam $1 \mathrm{mg}$.

In October 2010 she started having non-delusional persecutory thoughts which she recognized as "unrealistic". Mood and affect were within the normal range, and she didn't report any anxiety; she denied hallucinations. Thyroid function was: TSH $36 \mu \mathrm{U} / \mathrm{mL}$, fT3 $4 \mathrm{pg} / \mathrm{mL}$, fT4 $2 \mathrm{pg} / \mathrm{mL}$. Methilmazole was suspended, and the persecutory thoughts completely remitted after two weeks. In January 2011 the patient was euthymic, free of psychotic symptoms and only complained of anxiety. Her lab work indicated subclinical hyperthyroidism (TSH $0.03 \mu \mathrm{U} / \mathrm{mL}$, fT3 $4.3 \mathrm{pg} / \mathrm{mL}$, fT4 $16 \mathrm{pg} / \mathrm{mL}$ ). Anti thyroglobulin and andithyroperoxidase antibodies were 57 and $42 \mathrm{UI} / \mathrm{mL}$. Her HAM-A score was 15, her HAM-D score was 8, her BPRS score was 25 and her SAPS score was 0. Following endocrinological consult the patient was started on 5 mg of Methilmazole. She was most recently evaluated in May 2011: lab work showed normal thyroid function, and there were no psychiatric symptoms.

Table 1. Medication and psychiatric rating scales.

\begin{tabular}{lccccccc}
\hline $\begin{array}{c}\text { Jun } \\
\text { 6th }\end{array}$ & $\begin{array}{c}\text { Jul } \\
\text { 7th }\end{array}$ & $\begin{array}{c}\text { Jul } \\
\text { 24th }\end{array}$ & $\begin{array}{c}\text { Jul } \\
\text { 31st }\end{array}$ & $\begin{array}{c}\text { Aug } \\
\text { 23rd }\end{array}$ & $\begin{array}{c}\text { Sep } \\
\text { 21st }\end{array}$ & $\begin{array}{c}\text { Nov } \\
15 \text { th }\end{array}$ & $\begin{array}{c}\text { Jan } \\
\text { 3rd }\end{array}$ \\
\hline $\begin{array}{l}\text { Methilmazole (mg) } \\
\text { Haloperidol (mg) }\end{array}$ & 30 & 30 & 0 & & & \\
\hline SAPS & & 10 & & & & \\
BPRS & & 29 & & 2 & 0 \\
\hline
\end{tabular}

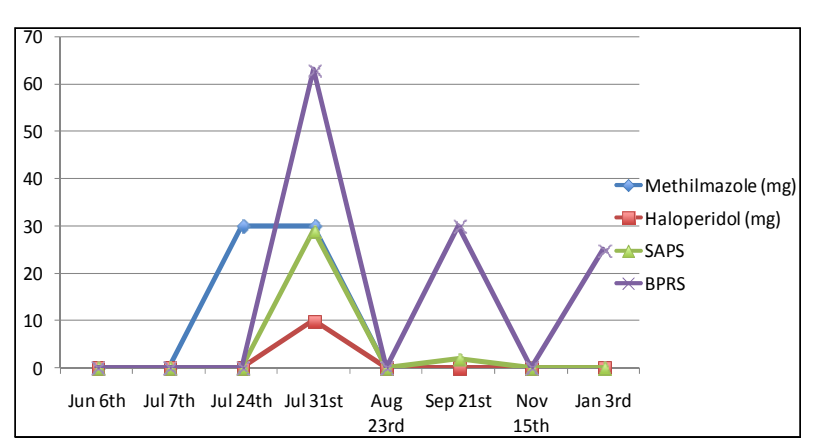

Table 2. Thyroid profile.

\begin{tabular}{|c|c|c|c|c|c|c|c|c|}
\hline & $\begin{array}{l}\text { Jun } \\
\text { 6th }\end{array}$ & $\begin{array}{l}\text { Jul } \\
7 \text { th }\end{array}$ & $\begin{array}{c}\text { Jul } \\
24 \text { th } \\
\end{array}$ & $\begin{array}{c}\text { Jul } \\
31 \mathrm{st} \\
\end{array}$ & $\begin{array}{l}\text { Aug } \\
\text { 23rd }\end{array}$ & $\begin{array}{l}\text { Sep } \\
21 \mathrm{st}\end{array}$ & $\begin{array}{l}\text { Nov } \\
15 \text { th }\end{array}$ & $\begin{array}{l}\text { Jan } \\
\text { 3rd }\end{array}$ \\
\hline $\mathrm{TSH}(\mu \mathrm{U} / \mathrm{mL})$ & 0.0015 & 0.001 & & 87 & 0.15 & 0.02 & 36.03 & 0.03 \\
\hline fT3 $(\mathrm{pg} / \mathrm{mL})$ & 14.6 & 12 & & 1.23 & 4.1 & 4.5 & 2 & 4.3 \\
\hline fT4 (pg/mL) & 37 & 35 & & 1.75 & 12 & 1.6 & 2 & 16 \\
\hline
\end{tabular}

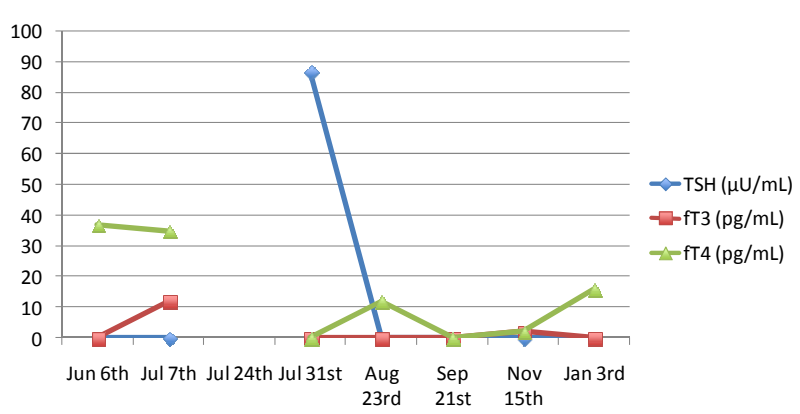

Table 3. Anti-thyroid antibodies.

\begin{tabular}{cccccccc}
\hline $\begin{array}{c}\text { Jun } \\
\text { 6th }\end{array}$ & $\begin{array}{c}\text { Jul } \\
\text { 7th }\end{array}$ & $\begin{array}{c}\text { Jul } \\
\text { 24th }\end{array}$ & $\begin{array}{c}\text { Jul } \\
\text { 31st }\end{array}$ & $\begin{array}{c}\text { Aug } \\
\text { 23rd }\end{array}$ & $\begin{array}{c}\text { Sep } \\
\text { 21st }\end{array}$ & $\begin{array}{c}\text { Nov } \\
\text { 15th }\end{array}$ & $\begin{array}{c}\text { Jan } \\
\text { 3rd }\end{array}$ \\
\hline Anti TG (UI/mL) & 133 & & & 60 & & 57 \\
Anti TPO (UI/mL) & 146 & & & 86 & & 42 \\
\hline
\end{tabular}

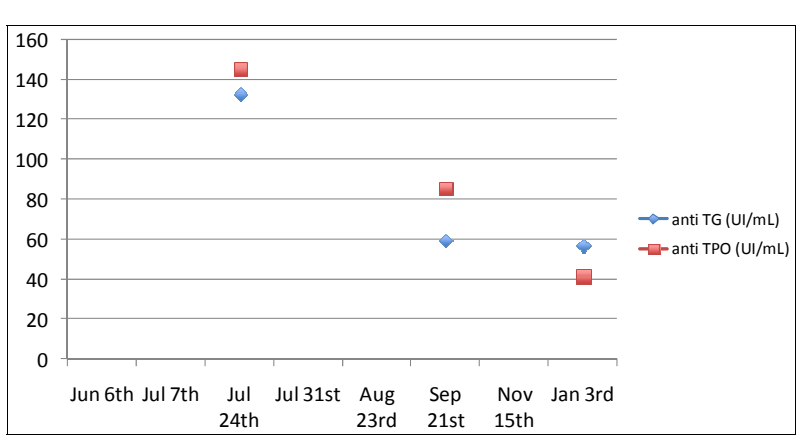

\section{DISCUSSSION}

While it is widely accepted that hypothyroidism can cause depressive symptoms, to the best of our knowledge only a few cases of psychotic symptoms associated with this condition have been described [3,5-10]. Based on the patient's clinical history, on the rapid onset and remission of symptoms and on the doses of medication that were prescribed (Table 1), as well as the lab values (Tables 2 and 3), we hypothesize that our patient's psychotic episode was caused by iatrogenic hypothyroidism.

\section{REFERENCES}

[1] Benvenga, S. Lapa, D. and Trimarchi, F. (2003) Don't forget the thyroid in the etiology of psychoses. The American Journal of Medicine, 1, 159-160.

[2] Roberts, C.G.P. and Ladenson, P.W. (2004) Hypothyroidism. Lancet, 363, 797-803. 


$$
\text { doi:10.1016/S0140-6736(04)15696-1 }
$$

[3] Heinrich, T.W. and Grahm, G. (2003) Hypothyroidism presenting as Psyhcosis: Myxedema madness revisited. Journal of Clinical Psychiatry, 5, 260-266.

[4] Hall, R.C. (1983) Psychiatric effects of thyroid hormone disturbance. Psychosomatics, 24, 7-18. doi:10.1016/S0033-3182(83)73255-X

[5] Azzopardi, L., Murfin, C., Sharda, A. and De Silva, N. (2010) Myxedema madness. British Medical Journal Case Reports.

[6] Brewer, C. (1969) Psyhcosis due to acute hypothyroidism during the administration of charbimazole. The British Journal of Psychiatry, 115, 1181-1183. doi:10.1192/bjp.115.527.1181
[7] Herridge, C.F. and Abey-Wickrama, I. (1969) Acute iatrogenic hypothyroid psychosis. British Medical Journal, 3, 154. doi: $10.1136 / \mathrm{bmj} .3 .5663 .154$

[8] Lehrmann, J.A. and Jain, S. (2002) Myxedema psychosis with grade II hypothyroidism. General Hospital Psychiatry, 24, 275-277. doi:10.1016/S0163-8343(02)00190-1

[9] Logothetis, J. (1963) Psychotic behaviour as the indicator of adult myxoedema. The Journal of Nervous and Mental Disease, 136, 561-568.

[10] Madakasira, S. and Hall, T.B. (1981) Capgras syndrome in a patient with myxedema. American Journal of Psychiatry, 138, 1506-1508. doi:10.1097/00005053-196306000-00008 